\title{
İlkokul Matematik Öğretim Programı Dersi Kazanımlarının Yenilenen Bloom Taksonomisine Göre İncelenmesi*
}

\section{Investigation of Primary School Mathematics Curriculum Lesson Acquisitions According to Renewed Bloom Taxonomy Osman AKTAN**}

• Geliş Tarihi: 06.02.2019 • Kabul Tarihi: 13.05.2019 • Çevrimiçi Yayın Tarihi: 21.06.2019

\section{$\ddot{O} \mathbf{z}$}

$\mathrm{Bu}$ araştırmanın amacı, İlkokul Matematik Öğretim Programında yer alan kazanımların Yenilenmiş Bloom Taksonomisine göre taksonomik düzeylerini belirlemektir. Araştırmada nitel araştırma yaklaşımı benimsenmiş olup, araştırma verileri doküman incelemesi yoluyla elde edilmiştir. Araştırma verileri, 2018 yılında güncellenen İlkokul Matematik Dersi Öğretim Programı kazanımlarından elde edilmiştir. Çalışmada 2018 yılında yayınlanan İlkokul Matematik Dersi Öğretim Programında (1. - 4.sınıflar) yer alan 229 kazanımın Yenilenmiş Bloom Taksonomisi’ne göre taksonomik düzeyleri belirlenmiştir. Verilerin analizinde içerik analizi tekniği kullanılmıştır Sınıf düzeyinde kazanımlar Yenilenmiş Bloom Taksonomisine göre incelenmiş, kazanımlar taksonominin alt basamaklarına göre karşılıkları belirlenmiş ve frekans olarak listelenmiştir. Araştırma bulgularına göre, İlkokul Matematik Öğretim Programında yer alan 1-4.sınıf ders kazanımların alt düzey bilişsel basamakları içeren uygulama, anlama ve hatırlama gibi alt düzey basamaklarda yoğunlaştığı, analiz, yaratma ve değerlendirme gibi üst düzey bilişsel basamakları içerin kazanımların az olduğu belirlenmiştir. Araştırma bulguları ilkokulda sınıf düzeyinde öğrencilere yönelik hazırlanan kazanımlarda üst düzey bilişsel basamakları içeren kazanımlara da daha fazla yer verilmesi önerilmiştir.

Anahtar sözcükler: İlkokul, matematik dersi öğretim programı, Bloom taksonomisi, kazanım.

Atıf:

Aktan, O. (2020). İlkokul matematik öğretim programı dersi kazanımlarının yenilenen Bloom Taksonomisine göre incelenmesi. Pamukkale Üniversitesi Ĕgitim Fakültesi Dergisi,48, 15-36. doi: 10.9779/pauefd.523545

\footnotetext{
* Bu makalenin bir bölümü 9-11 Mayıs 2018 tarihlerince Manisa Celal Bayar Üniversitesi’nde düzenlenen VIII. Uluslararası Eğitimde Araştırmalar Kongresi’nde sözlü bildiri olarak sunulmuştur.

** Dr., Öğretmen, Rehberlik ve Araştırma Merkezi, Düzce -Türkiye, ORCID: http://orcid.org/0000-0001-6583-3765, karakteregitimi@gmail.com
} 


\begin{abstract}
The purpose of this research is to determine the taxonomic levels of the acquisitions in Primary School Mathematics Teaching Program according to the revised Bloom Taxonomy. Qualitative research methods used in the research were document review. In this study, qualitative research approach was adopted and the research data were collected by the technique of document review. The research data were derived from the acquisitions of the Elementary School Mathematics Curriculum updated in 2018. The taxonomic levels of the 229 acquisitions in the study, which were published in the Primary School Mathematics Teaching Program (1st - 4th grades) published in 2018, were determined according to the Revised Bloom Taxonomy. In the analysis of the data, content analysis technique was used. Classroom acquisitions have been examined according to the revised Bloom Taxonomy; the equivalents of the acquisitions are determined according to the lower steps of the taxonomy and are listed as frequency. According to research findings, it was determined that the acquisitions of 1-4th grade course in Primary School Mathematics Teaching Program are concentrated in lower level steps such as application, understanding and remembering which includes lower level cognitive steps, and acquisitions including higher level cognitive steps such as analysis, creation and evaluation. The research findings suggest that higher grade cognitive steps should be included in the acquisitions prepared for the students at the class level in the primary school.
\end{abstract}

Keywords: Primary school, mathematics course curriculum, Bloom taxonomy, acquisitions

\title{
Cited:
}

Aktan, O. (2020). Investigation of primary school mathematics curriculum lesson acquisitions according to renewed Bloom Taxonomy. Pamukkale Üniversitesi Eğitim Fakültesi Dergisi, 48, 15-36. doi: 10.9779/pauefd.523545 


\section{Giriş}

Bilim ve teknoloji alanında yaşanan değişim ve gelişmelerin bireye, topluma yansımaları olduğu kadar, eğitim alanına da yansımaları olmakta ve buna paralel olarak eğitim alanında da değişiklikler söz konusu olmaktadır.

Eğitim, insanın hayata gelmesinden ölümüne kadar devam eden ve hayatımızın içinde yer alan dinamik toplumsal bir süreçtir. Bu süreç ile bireyin zihin, duygu, davranış ve sosyal becerileri gelişir. Eğitim; bireye yeni bilgi, tutum ve becerilerin kazandırılması (Akyüz, 2004, s.2; Varış, 1988, s.12), bireyin davranışlarında, kendi isteği doğrultusunda amaçlı olarak değişiklikler oluşturma süreci (Ertürk, 1994, s.12) olarak da ifade edilebilir. Eğitim faaliyetlerinden beklenen sonuçlara ulaşmak, eğitim-öğretim faaliyetlerinin kasitlı ve bir plan doğrultusunda sürdürülmesi ile doğrudan ilişkilidir. Eğitim programları, eğitim ve öğretime dönük faaliyetlerin planlı ve sistemli bir şekilde yürütülmesinde önemli rol oynamaktadır (Anderson vd., 2010). Eğitimin her kademesinde öğrencilere kazandırılmak istenen bilgi, tutum, beceri, değer ve öğrenme ürünleri okullarda öğretim programları aracıllğıyla planlı ve sistemli bir şekilde bireylere aktarılır.

Öğretim programı hakkında pek çok tanım yapılmıştır. Literatürde bu tanımlara ilişkin olarak; özel hedefler ve bunları tanımlayıcı öğe ve kritik davranışlar ve bunların öğrenilmiş olup olmadığını ortaya koyacak test durumları (Özçelik, 2013); eğitim programı içinde önemli yer tutan, belirlenen amaçlar doğrultusunda planlı olarak belirli bilgi ve beceri içeriğinden oluşan çalışmaların tümü (Varış, 1998, s.13); okulda öğretim yoluyla ya da okul dışında bireye kazandırılması amaçlanan dersin öğretimine dönük faaliyetleri içeren öğrenme yaşantıları (Demirel, 2009); bir hedef ile ilgili amaçları gerçekleştirmek için gerekli stratejilerin bulunduğu bir plan ya da yazılı metin (Ornstein ve Hunkins, 2004, s.6) şeklinde ifadelerin yer aldığı görülmektedir.

Eğitim programı hedef, içerik, öğrenme-öğretme süreci ve değerlendirme olmak üzere dört temel ögeden oluşmaktadır. Hedefler öğrenene kazandırılması amaçlanan istendik davranışları kapsamaktadır. İçerik bölümünü eğitim programında hedeflere uygun olarak hazırlanan konular oluşturmaktadır. Öğrenme-öğretme süreci hedefleri gerçekleştirilmek için seçilen içeriğe uygun olarak seçilecek öğrenme-öğretme kuramları, stratejileri ile yöntem tekniklerini içermektedir. Ölçme-değerlendirme öğesinde ise hedeflerin ölçülmesi, öğrenene kazandırılması amaçlanan davranışların kazandırılma düzeyi ve gerçekleştirilen eğitimin niteliği vurgulanmaktadır (Demirel, 2009). Ölçme ve değerlendirme hedef merkezli olarak gerçekleştirilir.

Hedef kavramı, yetiştirmek istediğimiz öğrenciye kazandırmayı amaçladığımız ve eğitim faaliyetleri ile kazandırılabilecek düzeydeki istendik özellikler olarak ifade edilebilir (Ertürk, 1994; s.26). Hedefler, öğretimin başlangıç aşamasını oluşturduğundan diğer öğretim programı öğelerine göre daha kritik bir öneme sahiptir. Hedeflerin doğru bir şekilde belirlenmesi, öğrencilere kazandırılması için uygun içeriğin hazırlanması ve hazırlanan içerikle hedeflerin amaca ulaşıp ulaşmadığının ölçülmesi ve ölçüm sonuçlarının değerlendirilmesi gerekir (Bümen, 2006). Öğretim programlarında yer alan kazanımların bilgi, tutum ve becerilerin birbirinin önkoşulu olacak şekilde düzeylerine göre basitten karmaşığa doğru 
sıralanması (Tutkun, 2012), öğrencilerin bilgiyi daha kolay yapılandırmalarını bu şekilde kalıcı öğrenmelerini sağlamak amacıyla yapılır (Anderson ve Krathwohl, 2001; Bloom, 1956).

Öğretim programında yer alan kazanımlar, öğretimin etkililiğini artırmak amacıyla öğretim hedefleri esas alınarak belli sıralama ve sinıflandırmalara tabi tutulur (Bloom, 1956; Krathwohl, 2002; Ornstein ve Hunkins, 2004; Tekin, 2009). Hedeflerin siralanması ve sınıflandırılmasına yönelik çalışmalar, 1950'li yıllarda Bloom ve arkadaşları tarafindan başlatılmıştır. Hedeflerin sıralanması ve sınıflandırılmasındaki temel amaç, öğrenme çıktılarının ölçmedeki etkinliğini artırmaktır. Bloom'un 1956 yılında yayınladığı bilişsel alan taksonomisi bilgi, kavrama, uygulama, analiz, sentez ve değerlendirme olmak üzere altı temel basamaktan oluşmaktadır (Ar1, 2013; Krathwohl, 2002; Schlesinger ve Persky, 2015). Eğitim alanında yeni gelişmelerle ortaya çıkan bilgi ve yönelimler doğrultusunda orijinal Bloom Taksonomisi'nde de değişiklikler yapılmıştır. Değişiklik gerekçesi olarak, orjinal Bloom Taksonomisi'nin üst düzey bilişsel becerileri tam olarak ölçemediği ifade edilmiştir (Anderson vd., 2010). Yenilenmiş taksonomik yapıda hedefler isim ve fiil halleri olmak üzere iki ayrı boyutta ele alınmıştır: Bunlar, Bilgi ve Bilişsel Süreç boyutudur. Bilgi boyutunda; olgulara dayanan bilgi, kavramsal bilgi, işlemsel bilgi ve biliş ötesi bilgi yer almaktadır. Yenilenmiş taksonomi de eski taksonomiye benzer altı basamaktan oluşmaktadır. (Anderson, 2005; Krathwohl, 2009). Yeni taksonomide üç basamağın ismi değiştirilmiş, iki basamağın ise yeri değiştirilmiştir. Orijinal taksonomide yer alan basamaklardan bilgi basamağı "hatırlamak", kavrama basamağı "anlamak" ve sentez basamağının ismi ise "analiz" olarak değiştirilmiştir. Bunların yanı sıra; değerlendirmek ve yaratmak basamaklarının yeri değiştirilmiş ve böylece yaratmak basamağı bilişsel süreç boyutunun son basamağı olmuştur (Krathwohl, 2009). Genel olarak, yeniden düzenlenen Bloom taksonomisinin; program geliştirmeye yönelik hedeflerin oluşturulması, öğrenme-öğretme süreçlerinin düzenlenmesi, ölçme ve değerlendirme uygulamaları ile öğretmen yetiştirme alanlarına dönük güncel eğilimleri içeren bir yenilik olduğu söylenebilir (Tutkun, Demirtaş, Erdoğan ve Arslan, 2010).

Matematik, insan zihninin çevresel etkilerden yola çıkarak günlük hayattaki problemleri çözmek için başvurduğu, sayma, hesaplama, ölçme ve çizme; mantıklı düşünmeyi geliştiren mantıklı bir disiplindir (Altun, 2013; Minisker, 2006). Matematik öğretiminin temel amac1; kişinin günlük hayatında gerekli olan matematiksel kavram ve sitemler yoluyla gerekli olan bilgi ve becerileri kazandırmak, ona problem çözmeyi öğretmek ve olayları problem çözme sistematiği içinde matematiksel bilgi ve becerilerle ele alan bir matematiksel düşünme biçimi kazandırmaktır (Altun, 2014). Uluslararası bir değerlendirme sınavı olan PISA'da öğrencilerin gerçek hayatta karşılaşabilecekleri bir problem karşısında sahip oldukları bilgi ve becerileri kullanabilme yeteneği, bilgileri analiz edebilme, akıl yürütme ve öğrenilen fen ve matematik kavramlarını kullanarak etkin bir iletişim kurma becerileri sınanmaktadır (MEB, 2016).

Günümüz matematik eğitiminde öğrencilere, günlük hayatta karşılaşılan sorunların çözümünde etkili olan problem çözme, karar verme, tahmin etme, mantıklı düşünme, akıl yürütme, algoritmik düşünme gibi önemli beceriler yeterince kazandırılamamaktadır (Olkun ve Toluk Uçar, 2014). Bu durum son yıllarda hem ulusal düzeyde yapılan merkezi ortak sınavlarda öğrencilerin matematik dersi ortalamaları 100 ham puan üzerinden ortalama 42 puan olması (MEB, 2015), uluslararası yapılan değerlendirmelerde Türk öğrencilerin matematik ortalamalarının diğer ülke ortalamalarının çok altında olmasından da (MEB, 2016; Mullis, 
Martin, Fierros, Goldberg ve Stemler, 2000; Mullis, Martin ve Foy, 2008; Mullis, Martin, Foy ve Hooper, 2016), anlaşılmaktadır.

İlgili alanyazını incelendiğinde farklı derslere yönelik olarak öğretim programlarında yer verilen hedeflerin, Yenilenmiş Bloom Taksonomisi (YBT)'ne göre incelendiği araştırmalar yapıldığı görülmektedir. Fen bilimleri öğretim programı kazanımlarının incelenmesi (Aktan ve Sevinç, 2018; Arı ve Gökler, 2012; Cangüven, Öz, Binzet ve Avc1, 2017; Güven ve Aydın, 2017; Yaz ve Kurnaz, 2017; Zorluoğlu, Şahintürk ve Bağrıyanık, 2017), fen ve teknoloji dersi sınav sorularının analizi (Arı ve Gökler, 2012; Arı ve İnci, 2015; Ayvacı ve Türkdoğan, 2010; Gökulu, 2015; Güleryüz ve Erdoğan, 2018; Tanık ve Saraçoğlu, 2011); ortaöğretim kimya dersi öğretim programı kazanımlarının incelenmesi (Üner, 2010; Zorluoğlu, Kızılaslan ve Sözbilir, 2016); Türkçe öğretim programı kazanımlarının incelenmesi (Aslan ve Atik, 2018; Çiftçi, 2010), Türkçe dersi sınav sorularının analizi (Çintaş-Yıldız, 2015; Eyüp, 2012), sosyal bilgiler öğretim programı kazanımlarının incelenmesi (Demir, 2015; Gazel ve Erol, 2011; Özdemir, Altıok ve Baki, 2015; Şenses, 2008) sosyal bilgiler dersi sınav sorularının analizi (Çalışkan, 2011; Şanlı ve Pınar, 2017; ortaokul matematik öğretim programı (6-8.sınıflar) kazanımlarının incelenmesi (Kablan, Baran ve Hazer, 2013), matematik dersi sınav sorularının analizi (Dursun ve Parim-Aydın, 2014; Karaman ve Bindak, 2017; Köğce ve Baki, 2009) Tarih öğretim programı kazanımlarının incelenmesi (Çolak ve Demircioğlu, 2010), Türk dili ve edebiyatı öğretim programı hedeflerinin incelenmesi (Tahaoğlu, 2014) İngilizce öğretim programı kazanımlarının ve sınav sorularının incelenmesi (Gökler, Aypay ve Arı, 2012), Türkiye Cumhuriyeti İnkılâp Tarihi ve Atatürkçülük dersi öğretim programı kazanımlarının incelenmesi (Gezer, Şahin, Sünkür ve Meral, 2014), ulusal düzeydeki sınav sorularının analizi (Baş ve Beyhan, 2012; Çevik, 2010; Dalak, 2015; Dursun ve Parim-Aydın, 2014, Gökler, Aypay ve Arı, 2012; Gökulu, 2015; Omar vd., 2012; Sönmez, Koç ve Çifçi, 2013; Tolan, 2011; Topçu, 2017), ders kitaplarında yer alan soru ve içeriklerin analizi (Eroğlu ve Sarar- Kuzu, 2014; Geçit ve Yarar, 2010; Girgin, 2012; Kahramanoğlu, 2013; Kuzu, 2013; Şenses, 2008; Üner, 2010; Üner, Akkuş ve Kormalı, 2014) ile ilgili çalışmaların yapıldığı görülmektedir.

Bilim ve teknolojide son yıllarda yaşanan hızlı değişim ve gelişmeler, bireyin ve toplumun değişen ihtiyaçları, öğrenme öğretme kuram ve süreçlerinde yaşanan yenilikler ve gelişmeler doğrultusunda, bireylerden beklenen roller dikkate alınarak, ilkokul öğrencilerine yönelik olarak hazırlanan İlkokul Matematik Dersi Öğretim Programı (İMDÖP)'nda 2015 ve 2018 y1lında öğretim programı güncellemeleri ve değişiklikler yapılmıştır (MEB, 2018). İlgili alanyazın incelendiğinde İMDÖP'da yer alan kazanımların incelenmesine yönelik bir araştırmaya rastlanılmamıştır. Son olarak 2018 y1lında güncellenen İMDÖP (1. 2. 3. ve 4. sınıf)'nda yer alan kazanımların incelenmesi yararlı olacaktır. Ayrıca öğretim programında yer alan kazanımların YBT'nin bilişssel süreç boyutuna göre düzeylerinin belirlenmesi, ilkokulda matematik dersinde öğretmenlere gerek öğrenme-öğretme süreçlerinde gerekse kazanım temelli ölçme ve değerlendirme faaliyetlerinde rehberlik yapması, dolayısıyla öğretimin niteliğini geliştirmesi beklenmektedir. Ayrıca öğretim programında yer alan kazanımların YBT'nin bilişssel süreç boyutuna göre düzeylerinin belirlenmesinin, öğretim programında yer alan hedeflerin program geliştirme ve program değerlendirme alanındaki çalışmalara da katkı sağlayacağı düşünülmektedir. Genel olarak değerlendirildiğinde araştırmanın program geliştirme, program değerlendirme ve matematik öğretimi konusunda alanyazına önemli katkılar sağlayacağı düşünülmektedir. Bu araştırmada, İMDÖP'da sınıf düzeyinde yer alan kazanımların 
YBT’nin bilişsel süreç boyutuna göre incelenerek kazanımların taksonomik düzeylerinin belirlenmesi amaçlanmıştır.

\section{Yöntem}

\section{Araştırmanın Modeli}

Araştırmada nitel araştırma yöntemi benimsenmiş olup, araştırma verilerinin elde edilmesinde doküman incelemesi kullanılmıştır. Doküman incelemesi, araştırılması amaçlanan olgu veya olgular hakkında yazılı bilgi kaynaklarının analiz edilmesidir (Yıldırım ve Şimşek, 2013). Doküman incelemesi, aynı zamanda tek başına kullanılabilen bir araştırma tekniğidir (Bowen, 2009). Çalışmada 2018 yılında yayınlanan İMDÖP'nda (1. - 4.sınıflar) yer alan 229 kazanımın (1.sınıf: 36 kazanım, 2.sınıf: 50 kazanım, 3.sınıf: 72 kazanım, 4.sınıf: 71 kazanım) YBT'ne göre taksonomik düzeyleri belirlenmiştir.

\section{Araştırmanın Veri Kaynağı}

Araştırmanın veri kaynağını Milli Eğitim Bakanlığı'nın 2018 yılında yayınlamış olduğu İMDÖP oluşturmuştur. Kazanımların taksonomik düzeylerini ve alt basamaklarını belirlemek amacıyla Bloom Taksonomisi ve YBT ile ilgili tez, makale, kitap ve diğer web kaynaklarından yararlanılmıştır.

\section{Verilerin Analizi}

Öncelikle ilgili alanyazında yapılan araştırmalar incelenerek Yenilenmiş Bloom Taksonomisi'nin bilişsel alan basamaklarına ve alt basamaklarına yönelik bir kodlama anahtarı oluşturulmuştur. İMDÖP'nda (1. - 4.sınıflar) yer alan yer alan 229 kazanımın taksonomi tablosundaki yerini belirlemek amacı ile araştırmacı tarafından her bir kazanımın fiil ifadeleri belirlenmiştir. Bazı kazanımlarda birden fazla fiil ifadesi olduğu belirlenmiş ve bu fiil ifadeleri ayrı ayrı olarak ele alınmıştır. Bu nedenden dolayı veri seti üzerinde elde edilen toplam kazanım sayıs1 (280) ile MDÖP'nda (1. - 4.sınıflar) yer alan toplam kazanım sayıs1 (229) farkl11ık göstermektedir. Örneğin;

\section{M.1.1.1.1. Rakamları okur ve yazar. (okur, yazar; 2 kazanım)}

M.1.1.1.7. Miktarı 10 ile 20 (10 ve 20 dâhil) arasında olan bir grup nesneyi, onluk ve birliklerine ayırarak gösterir, bu nesnelere karşıllk gelen sayıyı rakamlarla yazar ve okur. (gösterir, okur, yazar; 2 kazanım)

M.2.1.3.3. Doğal sayılarla yapılan çıkarma işleminin sonucunu tahmin eder ve tahminini işlem sonucuyla karşılaştırır. (tahmin eder, karşılaştırır; 2 kazanım)

Elde edilen verilerin geçerlik ve güvenirliğini sağlamak amacıyla; fiil ifadelerinin hangi basamağı içerdiği ile ilgili olarak; çalışmayı gerçekleştiren araştırmacının yanı sıra, nitel araştırma alanında iki ve matematik eğitimi alanında iki uzman olmak üzere, dört alan uzmanının da görüşleri alınarak yapılan kodlamalar karşılaştırılmış ve veri tablosuna son şekli verilmiştir. Döküman analizi ile elde edilen verilerin güvenirliği, Miles ve Huberman'ın (1994) "Görüş Birliği / (Görüş Birliği + Görüş Ayrıllı̆ı) x 100" formülü ile incelenmiştir. Uzmanlar arasındaki güvenirlik oranı $\% 88$ olarak tespit edilmiştir. 


\section{Bulgular}

Milli Eğitim Bakanlığı'nın 2018 yılında yayınlamış olduğu İlkokul Matematik Dersi Öğretim Programında (1. - 4. sınıflar) yer alan ders kazanımları, alanyazında yapılan araştırmalar incelenerek YBT'nin bilişsel alan basamaklarına ve alt basamaklarına yönelik oluşturulan kodlama anahtarına göre incelenmiştir. İMDÖP'nda (1. - 4.sınıflar) yer alan ders kazanımları YBT'nin bilişsel süreç boyutuna göre analiz edilerek aşağıda sıra ile verilmiştir. Tablo 1'de İMDÖP 1.sınıf ders kazanımlarının YBT'nin bilişsel süreç boyutuna göre analizi verilmiştir.

Tablo 1. İMDÖP'nda Yer Alan 1.Sınıf Ders Kazanımlarının YBT’nin Bilişsel Süreç Boyutuna Göre Analizi

\begin{tabular}{|c|c|c|c|c|}
\hline Ana basamak & Alt basamaklar & $\begin{array}{c}\text { Frekans } \\
\text { (f) }\end{array}$ & $\begin{array}{c}\text { Toplam } \\
\text { Frekans (f) }\end{array}$ & Toplam \% \\
\hline \multirow{7}{*}{ Hatırlama } & Okur & 4 & \multirow{7}{*}{11} & \multirow{7}{*}{24,1} \\
\hline & Sayar & 2 & & \\
\hline & Adlandırır & 1 & & \\
\hline & Belirler & 1 & & \\
\hline & Belirtir & 1 & & \\
\hline & Seçer & 1 & & \\
\hline & Tanır & 1 & & \\
\hline \multirow{4}{*}{ Anlama } & Açıklar & 3 & \multirow{4}{*}{7} & \multirow{4}{*}{15} \\
\hline & Kavrar & 2 & & \\
\hline & Fark eder & 1 & & \\
\hline & Örnek verir & 1 & & \\
\hline \multirow{8}{*}{ Uygulama } & Yapar & 4 & \multirow{8}{*}{15} & \multirow{8}{*}{32,6} \\
\hline & Yazar & 3 & & \\
\hline & Ölçer & 2 & & \\
\hline & Problem çözer & 2 & & \\
\hline & Gösterir & 1 & & \\
\hline & Kullanır & 1 & & \\
\hline & Bulur & 1 & & \\
\hline & Tamamlar & 1 & & \\
\hline \multirow{4}{*}{ Analiz } & Karşılaştırır & 5 & \multirow{4}{*}{11} & \multirow{4}{*}{24,1} \\
\hline & Siralar & 4 & & \\
\hline & İlişkilendirir & 1 & & \\
\hline & Sınıflandırır & 1 & & \\
\hline Değerlendirme & Kontrol eder & 1 & 1 & 2,1 \\
\hline Yaratma & Oluşturur & 1 & 1 & 2,1 \\
\hline Toplam & & & 46 & 100 \\
\hline
\end{tabular}

Tablo 1 incelendiğinde İMDÖP'nda yer alan 1. sınıf ders kazanımlarının YBT'nin bilişsel süreç boyutuna göre en çok uygulama basamağında yer aldığı, uygulama basamağını sırasıyla hatırlama, analiz, anlama, değerlendirme ve yaratma alt basamaklarının izlediği görülmektedir. İMDÖP'nda yer alan 1. sınıf ders kazanımları içinde değerlendirme ve yaratma basamaklarının en az temsil edilen bilişsel süreç basamakları olduğu görülmektedir. IMDÖP'nda yer alan 1.sınıf ders kazanımlarının yaklaşık \% 80'nin hatırlama, uygulama ve analiz alt basamaklarında yer aldığı görülmektedir. Tablo 2'de İMDÖP 2. sınıf ders kazanımlarının YBT’nin bilişsel süreç boyutuna göre analizi verilmiştir. 
Tablo 2. İMDÖP'nda Yer Alan 2. Sınıf Ders Kazanımlarının YBT'nin Bilişsel Süreç Boyutuna Göre Analizi

\begin{tabular}{|c|c|c|c|c|}
\hline Ana basamak & Alt basamaklar & $\begin{array}{l}\text { Frekans } \\
\text { (f) }\end{array}$ & $\begin{array}{c}\text { Toplam } \\
\text { Frekans (f) }\end{array}$ & Toplam \% \\
\hline \multirow{7}{*}{ Hatırlama } & Belirler & 3 & \multirow{7}{*}{10} & \multirow{7}{*}{15,15} \\
\hline & Tanır & 2 & & \\
\hline & Adlandırır & 1 & & \\
\hline & Belirtir & 1 & & \\
\hline & İfade eder & 1 & & \\
\hline & Okur & 1 & & \\
\hline & Sayar & 1 & & \\
\hline \multirow{4}{*}{ Anlama } & Fark eder & 5 & \multirow{4}{*}{13} & \multirow{4}{*}{19,70} \\
\hline & Açıklar & 4 & & \\
\hline & Tahmin eder & 3 & & \\
\hline & Zihinden bulur & 1 & & \\
\hline \multirow{10}{*}{ Uygulama } & Problem çözer & 8 & \multirow{10}{*}{26} & \multirow{10}{*}{39,40} \\
\hline & Yapar & 4 & & \\
\hline & Ölçer & 3 & & \\
\hline & Kullanır & 3 & & \\
\hline & Bulur & 2 & & \\
\hline & Tamamlar & 2 & & \\
\hline & Gösterir & 1 & & \\
\hline & Tartar & 1 & & \\
\hline & Toplar & 1 & & \\
\hline & Yazar & 1 & & \\
\hline \multirow{5}{*}{ Analiz } & Karşılaştırır & 6 & \multirow{5}{*}{11} & \multirow{5}{*}{16,70} \\
\hline & Siniflandirır & 2 & & \\
\hline & Siralar & 1 & & \\
\hline & Ayırt eder & 1 & & \\
\hline & Düzenler & 1 & & \\
\hline Değerlendirme & Kontrol eder & 2 & 2 & 3,03 \\
\hline \multirow{4}{*}{ Yaratma } & Çizer & 1 & \multirow{4}{*}{4} & \multirow{4}{*}{6,02} \\
\hline & Örüntü oluşturur & 1 & & \\
\hline & Model oluşturur & 1 & & \\
\hline & Grafik oluşturur & 1 & & \\
\hline Toplam & & & 66 & 100 \\
\hline
\end{tabular}

Tablo 2 incelendiğinde İMDÖP'nda yer alan 2. sınıf ders kazanımlarının YBT'nin bilişsel süreç boyutuna göre en çok uygulama basamağında yer aldığı, uygulama basamağını sırasıyla anlama, analiz, hatırlama, yaratma ve değerlendirme alt basamaklarının izlediği görülmektedir. İMDÖP'nda yer alan 2. sınıf ders kazanımları içinde değerlendirme ve yaratma basamaklarının en az temsil edilen bilişsel süreç basamakları olduğu görülmektedir. İMDÖP'nda yer alan 2. sınıf ders kazanımlarının yarısından fazlasının uygulama (\% 39,40) ve anlama (\% 19,70) alt basamaklarında yer aldığı görülmektedir. Tablo 3'te İMDÖP 3. sınıf ders kazanımlarının YBT’nin bilişsel süreç boyutuna göre analizi verilmiştir. 
Tablo 3. IMDÖP'nda Yer Alan 3. Sınıf Ders Kazanımlarının YBT'nin Bilişsel Süreç Boyutuna Göre Analizi

\begin{tabular}{|c|c|c|c|c|}
\hline Ana basamak & Alt basamaklar & $\begin{array}{l}\text { Frekans } \\
\text { (f) }\end{array}$ & $\begin{array}{c}\text { Toplam } \\
\text { Frekans (f) }\end{array}$ & $\begin{array}{c}\text { Toplam } \\
\%\end{array}$ \\
\hline \multirow[t]{7}{*}{ Hatırlama } & Belirler & 5 & \multirow{7}{*}{16} & \multirow{7}{*}{19} \\
\hline & Okur & 4 & & \\
\hline & Sayar & 2 & & \\
\hline & Belirtir & 2 & & \\
\hline & İfade eder & 1 & & \\
\hline & Tanır & 1 & & \\
\hline & İsimlendirir & 1 & & \\
\hline \multirow[t]{6}{*}{ Anlama } & Açıklar & 4 & \multirow{6}{*}{14} & \multirow{6}{*}{16,70} \\
\hline & Fark eder & 4 & & \\
\hline & Tahmin eder & 2 & & \\
\hline & Yorumlar & 2 & & \\
\hline & Zihinden çıkarır & 1 & & \\
\hline & Kavrar & 1 & & \\
\hline \multirow[t]{16}{*}{ Uygulama } & Problem çözer & 11 & \multirow{16}{*}{40} & \multirow{16}{*}{47,60} \\
\hline & Yapar & 5 & & \\
\hline & Ölçer & 5 & & \\
\hline & Yazar & 4 & & \\
\hline & Gösterir & 3 & & \\
\hline & Böler & 2 & & \\
\hline & Tamamlar & 1 & & \\
\hline & Kullanır & 1 & & \\
\hline & Çizer & 1 & & \\
\hline & Kaplar & 1 & & \\
\hline & Hesaplar & 1 & & \\
\hline & Bulur & 1 & & \\
\hline & Elde eder & 1 & & \\
\hline & Çarpar & 1 & & \\
\hline & Genişletir & 1 & & \\
\hline & Yuvarlar & 1 & & \\
\hline \multirow[t]{4}{*}{ Analiz } & Karşılaştııır & 3 & \multirow{4}{*}{7} & \multirow{4}{*}{8,40} \\
\hline & İlişkisini açıklar & 2 & & \\
\hline & Siralar & 1 & & \\
\hline & Düzenler & 1 & & \\
\hline Değerlendirme & Kontrol eder & 3 & 3 & 3,60 \\
\hline \multirow[t]{4}{*}{ Yaratma } & Çizim yapar & 2 & \multirow{3}{*}{4} & \multirow{3}{*}{4,70} \\
\hline & Kağıda çizer & 1 & & \\
\hline & Tablo oluşturur & 1 & & \\
\hline & Toplam & & 84 & 100 \\
\hline
\end{tabular}

Tablo 3 incelendiğinde İMDÖP'nda yer alan 3. sınıf ders kazanımlarının YBT'nin bilişsel süreç boyutuna göre en çok uygulama basamağında yer aldığı, uygulama basamağını sırasıyla hatırlama, anlama, analiz, yaratma ve değerlendirme alt basamaklarının izlediği görülmektedir. İMDÖP'nda yer alan 3. sınıf ders kazanımları içinde değerlendirme ve yaratma 
basamaklarının en az temsil edilen bilişsel süreç basamakları olduğu görülmektedir. İMDÖP'nda yer alan 3. sınıf ders kazanımlarının yaklaşık olarak yarısının $(\% 47,60)$ uygulama alt basamağında yer aldığı görülmektedir. Tablo 4'te İMDÖP 4. sınıf ders kazanımlarının YBT’nin bilişsel süreç boyutuna göre analizi verilmiştir.

Tablo 4. İMDÖP'nda Yer Alan 4. Sınıf Ders Kazanımlarının YBT'nin Bilişsel Süreç Boyutuna Göre Analizi

\begin{tabular}{|c|c|c|c|c|}
\hline Ana basamak & Alt basamaklar & $\begin{array}{l}\text { Frekans } \\
\text { (f) }\end{array}$ & $\begin{array}{c}\text { Toplam } \\
\text { Frekans (f) }\end{array}$ & $\begin{array}{c}\text { Toplam } \\
\%\end{array}$ \\
\hline \multirow[t]{7}{*}{ Hatırlama } & Belirler & 6 & \multirow{7}{*}{14} & \multirow{7}{*}{16,70} \\
\hline & Tanır & 2 & & \\
\hline & İsimlendirir & 2 & & \\
\hline & Sayar & 1 & & \\
\hline & Belirtir & 1 & & \\
\hline & İfade eder & 1 & & \\
\hline & Okur & 1 & & \\
\hline \multirow[t]{6}{*}{ Anlama } & Açıklar & 10 & \multirow{6}{*}{17} & \multirow{6}{*}{20,30} \\
\hline & Tahmin eder & 3 & & \\
\hline & Fark eder & 1 & & \\
\hline & Örneklendirir & 1 & & \\
\hline & Zihinden belirler & 1 & & \\
\hline & Yorumlar & 1 & & \\
\hline \multirow{12}{*}{ Uygulama } & Problem çözer & 11 & \multirow{12}{*}{32} & \multirow{12}{*}{38} \\
\hline & Yapar & 3 & & \\
\hline & Çarpar & 3 & & \\
\hline & Kullanır & 3 & & \\
\hline & Gösterir & 2 & & \\
\hline & Böler & 2 & & \\
\hline & Yazar & 2 & & \\
\hline & Ölçer & 2 & & \\
\hline & Toplar & 1 & & \\
\hline & Çıkarır & 1 & & \\
\hline & Yuvarlar & 1 & & \\
\hline & Çözümler & 1 & & \\
\hline \multirow[t]{5}{*}{ Analiz } & Karşılaştırır & 5 & \multirow{5}{*}{10} & \multirow{5}{*}{11,90} \\
\hline & Dönüştürür & 2 & & \\
\hline & İlişkilendirir & 1 & & \\
\hline & Siralar & 1 & & \\
\hline & Sinıflandırır & 1 & & \\
\hline Değerlendirme & Kontrol eder & 2 & 2 & 2,40 \\
\hline \multirow[t]{5}{*}{ Yaratma } & Oluşturur & 5 & \multirow{4}{*}{9} & \multirow{4}{*}{10,70} \\
\hline & Kağıda çizer & 2 & & \\
\hline & Modelle gösterir & 1 & & \\
\hline & Grafik oluşturur & 1 & & \\
\hline & Toplam & & 84 & 100 \\
\hline
\end{tabular}


Tablo 4 incelendiğinde İMDÖP'nda yer alan 4. sınıf ders kazanımlarının YBT'nin bilişsel süreç boyutuna göre en çok uygulama basamağında yer aldığı, uygulama basamağını sırasıyla anlama, hatırlama, analiz, yaratma ve değerlendirme alt basamaklarının izlediği görülmektedir. İMDÖP'nda yer alan 4. sınıf ders kazanımları içinde değerlendirme, yaratma ve analiz basamaklarının en az temsil edilen bilişsel süreç basamakları olduğu görülmektedir. İMDÖP'nda yer alan 4. sınıf ders kazanımlarının yaklaşık olarak dörtte üçünün (\% 75) hatırlama, anlama ve uygulama alt basamaklarında yer aldığ görülmektedir. Tablo 5'te IMDÖP'nda yer alan kazanımların sınıf düzeyinde YBT'nin bilişsel süreç boyutuna göre analizi verilmiştir.

Tablo 5. İMDÖP'nda Yer Alan Kazanımların Sınıf Düzeyinde YBT’nin Bilişsel Süreç Boyutuna Göre Analizlerinin Karşılaştırılması

\begin{tabular}{lccccc}
\hline Ana basamak & $\begin{array}{c}\text { 1.Sinıf } \\
\text { Frekans } \\
\text { (f) }\end{array}$ & $\begin{array}{c}\text { 2.Sinıf } \\
\text { Frekans } \\
\text { (f) }\end{array}$ & $\begin{array}{c}\text { 3.Sinıf } \\
\text { Frekans } \\
\text { (f) }\end{array}$ & $\begin{array}{c}\text { 4.Sinıf Frekans } \\
\text { (f) }\end{array}$ & $\begin{array}{c}\text { Toplam } \\
\text { Frekans } \\
\text { (f) }\end{array}$ \\
\hline Hatırlama & 11 & 10 & 16 & 14 & 51 \\
Anlama & 7 & 13 & 14 & 17 & 51 \\
Uygulama & 15 & 26 & 40 & 32 & 113 \\
Analiz & 11 & 11 & 7 & 10 & 39 \\
Değerlendirme & 1 & 2 & 3 & 2 & 8 \\
Yaratma & 1 & 4 & 4 & 9 & 18 \\
\hline Toplam & 46 & 66 & 84 & 84 & 280 \\
\hline
\end{tabular}

Tablo 5 incelendiğinde İMDÖP'nda yer alan 1-4. sınıf ders kazanımları incelendiğinde YBT’nin bilişsel süreç boyutuna göre tüm sınıf düzeylerinde uygulama basamağına yönelik kazanımların en fazla yer aldığı görülmektedir. Uygulama basamağını sırasıyla hatırlama ve anlama basamaklarına yönelik kazanımların takip ettiği görülmektedir. İMDÖP'nda yer alan 14. sınıf ders kazanımları incelendiğinde YBT'nin bilişsel süreç boyutuna göre tüm sınıf düzeylerinde değerlendirme ve yaratma alt basamağının en az temsil edilen basamaklar olduğu belirlenmiştir. Grafik 1'de İMDÖP'nda yer alan 1-4. sınıf ders kazanımlarının YBT'nin bilişsel süreç boyutuna göre tüm sınıf düzeylerine göre analizleri grafik olarak verilmiştir.

\section{Boyutuna Göre Analizlerinin Karşılaştırılması}

Grafik 1 incelendiğinde İMDÖP'nda yer alan 1-4.sınıf ders kazanımlar incelendiğinde YBT'nin bilişsel süreç boyutuna göre tüm sınıf düzeylerinde yer alan kazanımların genel olarak \% 40 uygulama, \% 18 hatılama, \% 18 anlama, \% 14 analiz, \% 7 yaratma ve \% 3 değerlendirme basamağına ait olduğu belirlenmiştir. Araştırma bulgularına göre, adı geçen öğretim programında yer alan kazanımların en fazla, YBT'nin bilişsel süreç boyutuna göre, uygulama basamağında yer aldığı görülmektedir. Değerlendirme ve yaratma basamaklarında yer alan kazanımlar diğer basamaklara oranla en azdır. Uygulama basamağından sonra en fazla kazanıma sahip basamaklar sırasıyla; hatırlama, anlama ve analiz basamağıdır. 


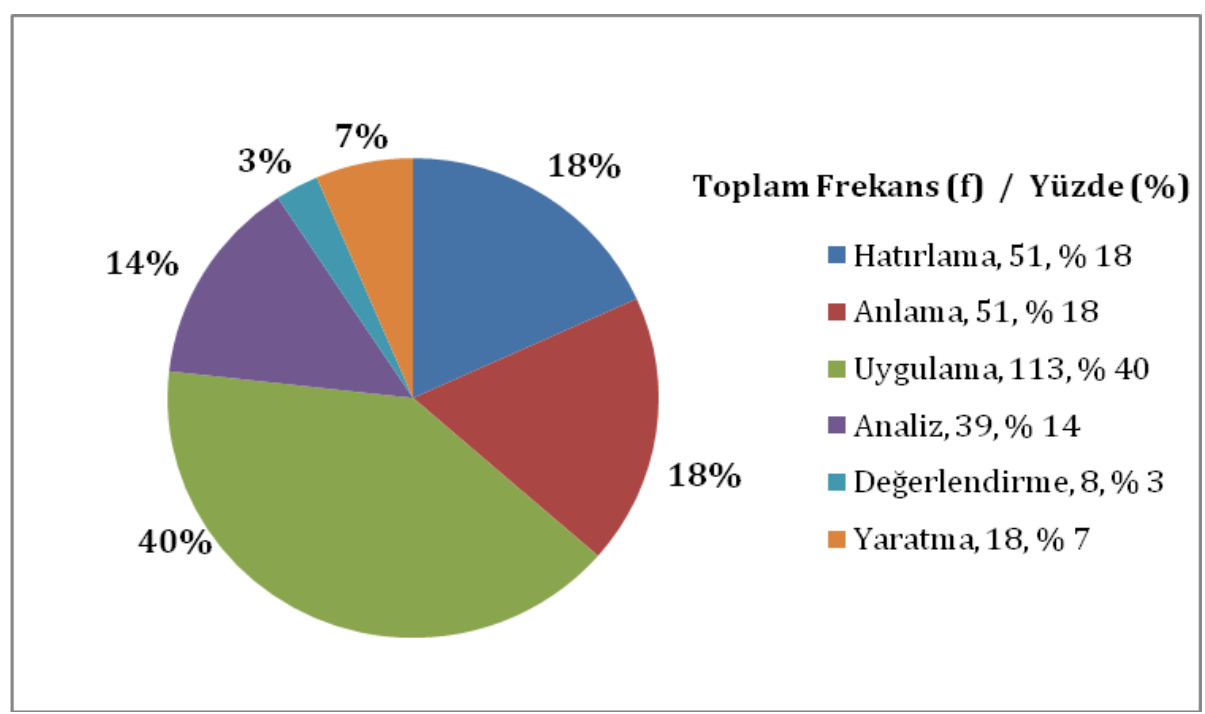

\section{Grafik 1. IMDÖP'nda Yer Alan Kazanımların Sınıf Düzeyinde YBT’nin Bilişsel Süreç}

\section{Tartışma ve Sonuç}

$\mathrm{Bu}$ araştırmada İMDÖP'nda yer alan 1-4. sınıf ders kazanımları Yenilenmiş Bloom Taksonomisi'nin bilişsel süreç boyutuna göre incelenerek taksonomik düzeyleri belirlenmiştir. Kazanımlar alanyazından belirlenen anahtar kelimeler kullanılarak sınıflandırılmıştır. Araştırma sonuçları incelendiğinde, İMDÖP'nda yer alan 1-4. sınıf ders kazanımların alt düzey bilişsel basamakları içeren uygulama, anlama ve hatırlama gibi alt düzey basamaklarda yoğunlaştığı, analiz, yaratma ve değerlendirme gibi üst düzey bilişsel basamakları içerin kazanımların az olduğu belirlenmiştir. Bu durum İMDÖP'nda yer alan 1-4. sınıf ders kazanımlarının, üst düzey bilişsel süreç basamaklarınca yeterince temsil edilmediğini göstermektedir. Ayrıca, kazanımların bu şekilde orantısız dağılımı, bilişsel süreç boyutunda yer alan bütün basamakları yeterli şekilde temsil edilme durumu da tam olarak karşılamamaktadır (Anderson vd., 2010). Matematik öğretiminin temel amacı; kişinin günlük hayatında gerekli olan matematiksel kavram ve sitemler yoluyla matematiksel bilgi ve becerileri kazandırmak, ona problem çözmeyi öğretmek ve olayları problem çözme yaklaşımı içinde matematiksel bilgi ve becerilerle ele alan bir düşünme biçimi kazandırmaktır (Altun, 2014, s.15). Bu amaç doğrultusunda İMDÖP'nın bireyleri “üst bilişsel becerilerin kullanımına yönlendiren bir öğretim programı perspektifiyle, üst bilişsel becerileri kullanan, anlamlı ve kalıcı öğrenen bireyler yetiştirilmesi amaçlanmaktadır (MEB, 2018).

Araştırma bulgularına dayalı olarak öğretim programında öğrencilere üst düzey bilişsel becerileri kazandıracak kazanımlara daha az yer verildiği, bu bakımdan kazanımların öğretim programı perspektifinin gerisinde kaldığı söylenebilir. Ayrıca matematik öğretiminin işleme dayalı olması nedeniyle kazanımlarda uygulama basamağına daha fazla yer verildiği söylenebilir. Fakat uygulama basamağında edinilen işlemsel becerilerin üst düzey beceriler içinde temel olup, geliştirilmesi bakımından üst düzey becerilere yönelik kazanımların az olması, öğrencilerin üst düzey düşünme becerilerini geliştirmede yeterli olmayabilir. Yapılan araştırma sonuçları da üst düzey düşünme becerilerinin öğrencilerin problem çözmedeki başarısını arttırdığı, bu sayede öğrencilerin zihinsel süreçleri daha etkili kullandıklarını ortaya 
koymaktadır (Demir, 2016; Kahramanoğlu ve Deniz, 2017; Kaplan, Duran ve Baş, 2016; Karakelle, 2012; Kramarski, Mevarech, Arami, 2002; Schoenfeld, 1985).

Yapılan araştırmalar incelendiğinde ilkokul matematik öğretim programının YBT’nin bilişsel süreç boyutuna göre incelendiği bir araştırma olmamakla birlikte, matematik ders kazanımlarına yönelik olarak Kablan, Baran ve Hazer (2013) tarafindan ortaokul matematik öğretim programı (6-8. sınıflar) kazanımlarının incelendiği görülmektedir. Araştırmada elde edilen sonuçlara göre, ortaokul matematik öğretim programı (6-8. sınıflar) kazanımlarının değerlendirme ve yaratma basamağında çok az yer aldığı, genel olarak kazanımların anlama ve uygulama basamağında yoğunlaştığı belirlenmiştir. Araştırma bulguları bakımından ilkokul ve ortaokul matematik öğretim programında yer alan kazanımların Yenilenmiş Bloom Taksonomisi'nin bilişsel süreç boyutunda benzer dağılım gösterdiği söylenebilir. Bu durumun nedeni olarak ortaokul matematik öğretim programının ilkokul matematik öğretim programı temel alınarak yapılandırılması ifade edilebilir.

Matematik dersi sınav sorularının analiz edilmesine yönelik bazı araştırmalarda da (Dursun, 2014; Dursun ve Parim-Aydın, 2014; Karaman ve Bindak, 2017; Köğce ve Baki, 2009) araştırma bulgularımızı destekler biçimde öğretmenler tarafından hazırlanan sınav sorularında YBT'nin bilişsel süreç boyutunun uygulama alt basamağına ağırlık verildiği, analiz, yaratma ve değerlendirme gibi üst düzey basamaklara yeterli yer verilmediği belirlenmiştir.

Matematik öğretim programı dışında farklı öğretim programlarda yer alan kazanımların YBT'nin bilişsel süreç boyutuna göre incelendiği araştırma sonuçları da (Aktan ve Sevinç, 2018; Ar1 ve İnci, 2015; Aslan ve Atik, 2018; Arsal, 2012; Cangüven, Öz, Binzet ve Avc1, 2017; Çiftçi, 2010; Demir, 2015; Gazel ve Erol, 2011; Güven ve Aydın, 2017, Özdemir, Altıok ve Baki, 2015; Şenses, 2008; Tahaoğlu, 2014; Üner, 2010; Yaz ve Kurnaz, 2017; Zorluoğlu, Kızılaslan ve Sözbilir, 2016; Zorluoğlu, Şahintürk ve Bağrıyanık, 2017) araştırma bulgularımızı desteklemektedir. Gezer, Şahin, Sünkür ve Meral (2014) tarafindan Türkiye Cumhuriyeti İnkılâp Tarihi ve Atatürkçülük Dersi Öğretim Programı kazanımlarının araştırmada ise araştırma bulgularımızın aksine, Yenilenmiş Bloom Taksonomisi'nin bilişsel süreç boyutuna göre üst düzey bilişsel basamakların kazanımlarda daha fazla yer aldığı belirlenmiştir.

Farklı derslere yönelik olarak hazırlanan sınav sorularının YBT'nin bilişsel süreç boyutuna göre incelendiği araştırma sonuçları da (Ar1 ve İnci, 2015; Ayvacı ve Türkdoğan, 2010; Çintaş-Yıldız, 2015; Çolak ve Demircioğlu, 2010; Eyüp, 2012; Gökulu, 2015; Güleryüz ve Erdoğan, 2018; Tanık ve Saraçoğlu, 2011) araştırma bulgularımızı desteklemektedir. Yapılan analizler sonucunda sınav sorularında YBT'nin bilişsel süreç boyutunun alt basamakları olan hatırlama, anlama ve uygulama basamaklarına ağırlık verildiği, analiz, yaratma ve değerlendirme gibi üst düzey basamaklara ise sınav sorularında yeterli yer verilmediği belirlenmiştir. Aynı şekilde ulusal düzeydeki sınav sorularının analizine yönelik yapılan araştırma sonuçları da (Baş ve Beyhan, 2012; Çevik, 2010; Dalak, 2015; Dursun ve ParimAydın, 2014; Sönmez, Koç ve Çifçi, 2013; Tolan, 2011; Topçu, 2017) araştırma bulgularımızla örtüşmektedir. Yapılan analizler sonucunda ulusal düzeyde öğrencilere sorulan sinav sorularında Yenilenmiş Bloom Taksonomisi'nin bilişsel süreç boyutunun alt basamakları olan hatırlama, anlama ve uygulama basamaklarına ağırlık verildiği, analiz, yaratma ve değerlendirme gibi üst düzey basamaklara ise sınav sorularında yeterli yer verilmediği belirlenmiştir. 
Ders kitaplarında yer alan soru ve içeriklerin YBT'nin bilişsel süreç boyutuna göre analiz edildiği araştırmalarda da (Eroğlu ve Sarar- Kuzu, 2014; Geçit ve Yarar, 2010; Girgin, 2012; Kahramanoğlu, 2013; Kuzu, 2013; Şenses, 2008; Üner, 2010; Üner, Akkuş ve Kormal1, 2014) araştırma bulgularımızı destekler biçimde, hem ders kitaplarında yer alan sorularda hem de ders kitabı içeriklerinde YBT'nin bilişsel süreç boyutunun alt basamakları olan hatırlama, anlama ve uygulama basamaklarına ağırlık verildiği, analiz, yaratma ve değerlendirme gibi üst düzey basamaklara ise sınav sorularında yeterli yer verilmediği belirlenmiştir.

Genel olarak araştırma sonuçları incelendiğinde, İMDÖP'nda yer alan 1-4. sınıf ders kazanımların alt düzey bilişsel basamakları içeren uygulama, anlama ve hatırlama gibi alt düzey basamaklarda yoğunlaştığı, analiz, yaratma ve değerlendirme gibi üst düzey bilişsel basamakları içerin kazanımların az olduğu belirlenmiştir. Yapılan araştırmalar incelendiğinde ilkokul matematik öğretim programının YBT'nin bilişsel süreç boyutuna göre incelendiği bir araştırma olmamakla birlikte, ortaokul matematik öğretim programında (6-8. sınıflar), matematik dersine yönelik hazırlanan sınav sorularında, matematik dersi dışındaki öğretim programlarındaki kazanımlarda, farklı derslere yönelik hazırlanan sınav sorularında, ders kitaplarında yer alan soru ve içeriklerde, ulusal düzeyde yapılan sınav sorularında da benzer şekilde alt düzey bilişsel basamakları içeren uygulama, anlama ve hatırlama gibi basamaklarda yoğunlaştığı, analiz, yaratma ve değerlendirme gibi üst düzey bilişsel basamakları içerin kazanımların az olduğu belirlenmiştir. Araştırma sonuçları doğrultusunda matematik eğitiminde, gerek öğretim programlarında gerekse matematik dersine yönelik hazırlanan sınav soruları ve ulusal düzeydeki soruların öğrencilere üst düzey bilişsel becerileri kazandırmada yeterli olmadığı söylenebilir. Bu durumun yansıması olarak öğrencilere, çağımızın ihtiyacı olan problem çözme, karar verme, tahmin etme, mantıklı düşünme akıl yürütme, algoritmik düşünme gibi günümüzde önemli olan beceriler yeterince kazandırılamamaktadır (Olkun ve Toluk Uçar, 2014). Gerek öğretim programlarında, gerekse öğretim programı ile ilgili diğer öğretimsel çalışmalarda alt düzey bilişsel becerilere ağırlık verilmesi, ulusal düzeyde yapılan merkezi ortak sınavlarda öğrencilerin matematik derslerinde düşük puanlar almalarında (MEB, 2015) etkili olduğu söylenebilir. Bununla birlikte üst düzey bilişsel becerilerin ölçüldüğü uluslararası yapılan değerlendirmelerde, Türk öğrencilerin matematik dersi başarı ortalamalarının diğer ülke ortalamalarının çok altında olmasının nedenleri arasında (MEB, 2016; Mullis, Martin, Fierros, Goldberg ve Stemler, 2000; Mullis, Martin ve Foy, 2008; Mullis, Martin, Foy ve Hooper, 2016) ilkokul ve ortaokul matematik dersi öğretim programında alt düzey bilişsel becerilere daha fazla yer verilmesi ve üst düzey bilişsel becerilerin öğretim programlarında daha az yer alması sayılabilir.

Araştırma bulguları doğrultusunda İMDÖP'nın öğretim perspektifine uygun olarak ilkokulda sınıf düzeyinde öğrencilere yönelik hazırlanan kazanımlarda üst düzey bilişsel basamakları içeren kazanımlara (analiz, değerlendirme, yaratma) daha fazla yer verilmesi önerilmektedir. Öğretim programlarıyla doğrudan ilişkili olan diğer öğretimsel çalışmalarda (ders kitabı içerikleri, ders kitaplarında yer alan sorular, derse yönelik sınav soruları ve ulusal düzeyde sınav soruları) da üst düzey bilişsel becerilere yer verilmesi gerekmektedir. 


\section{Kaynakça}

Akyüz, Y. (2004). Türk eğitim tarihi. Ankara: PegemA Yayıncılık.

Aktan, O. ve Sevinç, Ö. S. (2018). İlkokul Fen Bilimleri Dersi Öğretim Programı ders kazanımlarının yenilenen Bloom Taksonomisine incelenmesi. II. Uluslararası Multidispiliner Çalışmaları Kongresi, Adana. 4-5 Mayıs 2018.

Altun, M. (2013). Eğitim fakülteleri ve sinıf öğretmenleri için matematik ögretimi (18.baskı). Bursa: Aktüel Alfa.

Altun, M. (2014). Ortaokullarda (5, 6, 7 ve 8. sinuflarda) matematik ögretimi. Bursa: Alfa Akademi Yayıncilik.

Anderson, L. W. \& Krathwohl, D. R. (Eds.). (2001). Taxonomy for learning, teaching and assessing: A revision of bloom's taxonomy of educational objectives. Needham Heights, MA: Allyn \& Bacon.

Anderson, L. W. (2005). Objectives, evaluation, and the improvement of education. Studies in Educational Evaluation, 31 (2-3), 102-113.

Anderson, L. W. \& Krathwohl, D. R. \& diğ. (Eds.) (2010). Öğrenme, ögretim ve değerlendirme ile ilgili bir sinıflama. Bloom'un eğitimin hedefleri ile ilgili sınıflamasının güncelleştirilmiş biçimi. (Çev. D. A. Özçelik). Ankara: Pegem Akademi.

Arı, A. (2013). Bilişsel alan sınıflamasında yenilenmiş Bloom, Solo, Fink, Dettmer taksonomileri ve uluslararası alanda tanınma durumları. Uş̧ak Üniversitesi Sosyal Bilimler Dergisi, 6 (2), 259-290.

Arı, A. ve Gökler, Z. S. (2012). İlköğretim fen ve teknoloji dersi kazanımları ve SBS sorularının yeni Bloom taksonomisine göre değerlendirilmesi. X. Ulusal Fen Bilimleri ve Matematik Eğitimi Kongresi, Niğde. 20-30 Haziran 2012.

Arı, A. ve İnci T. (2015). Sekizinci sınıf fen ve teknoloji dersine ilişkin ortak sınav sorularının değerlendirilmesi. Uşak Üniversitesi Sosyal Bilimler Dergisi, 8 (4), 17-50.

Arsal, Z. (2012). İlköğretim fen ve teknoloji dersi öğretim programı kazanımlarının yapılandırmacılık ilkelerine göre değerlendirilmesi. Eğitim Programları ve Öğretim Dergisi. 2(3), 1-14.

Aslan, M. ve Atik, U. (2018). 2015 ve 2017 İlkokul Türkçe dersi öğretim programı kazanımlarının revize edilmiş Bloom taksonomisine göre incelenmesi. Uluslararası Türkçe Edebiyat Kültür Eğitim Dergisi, 7(1), 528-547.

Ayvacı, H. ve Türkdoğan, A., (2010). Yeniden yapılandırılan Bloom taksonomisine göre fen ve teknoloji dersi yazılı sorularının incelenmesi. Türk Fen Eğitimi Dergisi, 7(1).13-25

Baş, G. ve Beyhan, Ö. (2012). Seviye belirleme sınavı (SBS) ingilizce sorularının bilişsel alan taksonomisine göre değerlendirilmesi. Uluslararası Hakemli Sosyal Bilimler E-Dergisi, 31 (2), $1-18$.

Bloom, B. S. (1956). Taxonomy of educational objectives, the classification of educational goals, handbook I: Cognitive Domain. New York: David McKay Company.

Bowen, A. G. (2009). Document analysis as a qualitative research method. Qualitative Research Journal, $9(2), 27-40$.

Bümen, N. T. (2006). Program geliştirmede bir dönüm noktası: Yenilenmiş Bloom taksonomisi. Eğitim ve Bilim, 31 (142), 3-14.

Cangüven, H. D., Öz, O., Binzet, G. ve Avcı, G. (2017). Milli Eğitim Bakanlığı 2017 fen bilimleri taslak programının yenilenmiş Bloom taksonomisine göre incelenmesi. International Journal of Eurasian Education and Culture, 2, 62-80.

Çalışkan, H. (2011). Öğretmenlerin hazırladığı sosyal bilgiler dersi sınav sorularının değerlendirilmesi. Eğitim ve Bilim, 36 (160), 120-132.

Çevik, Ş. (2010). Ortaöğretim 9, 10 ve 11. sinuf fizik ders kitaplarında bulunan sorular ile 2000- 2008 yılları arasında ögrenci seçme ve yerleştirme sinavlarında sorulan fizik sorularının Bloom taksonomisi açısından incelenmesi ve karşılaş̧tırılması. Yayınlanmamış Yüksek lisans Tezi. Dicle Üniversitesi Fen Bilimleri Enstitüsü, Diyarbakır. 
Çiftçi, Ö. (2010). İlköğretim Türkçe öğretim programında 5. sınıfa ait okuduğunu anlama kazanımlarının bilişsel beceriler yönünden değerlendirilmesi. Journal of Türklük Bilimi Araştırmaları, 27(2), 161-184.

Çintaş-Yıldız, D. (2015). Türkçe dersi sınav sorularının yeniden yapılandırılan Bloom taksonomisine göre analizi. Gaziantep University Journal of Social Sciences, 14 (2), 479-497.

Çolak, K. ve Demircioğlu, İ. H. (2010). Tarih dersi sınav sorularının Bloom taksonomisinin bilişsel alan düzeyi açısından sınıflandırılması. Milli Eğitim Dergisi, 187 (7) 160-171.

Dalak, O. (2015). TEOG sinav sorulart ile 8. sinıf ögretim programlarındaki ilgili kazanımların yenilenmiş Bloom taksonomisine göre incelenmesi.Yayımlanmamış yüksek lisans tezi. Gaziantep Üniversitesi Eğitim Bilimleri Enstitüsü, Gaziantep

Demir, P. (2015). Yenilenmiş Bloom taksonomisi'ne göre 2005 yll sosyal bilgiler öğretim programında yer alan kazanımlar ve seviye belirleme sinav sorulart. Yüksek Lisans Tezi. On dokuz Mayıs Üniversitesi Eğitim Bilimleri Enstitüsü, Samsun.

Demir, Ö. (2016). Ortaokul öğrencilerinde problem çözme ve bilişsel farkındalık beceri düzeylerinin incelenmesi. Kastamonu Eğitim Dergisi, 24 (2), 789-802.

Demirel, Ö. (2009). Kuramdan uygulamaya eğitimde program geliştirme (12. Bask1). Ankara: Pegem A Yayıncilik.

Dursun, A. (2014). YGS 2013 matemetik sorulart ile ortaögretim 9.sinıf matematik sinav sorularının Bloom taksonomisi ve ögretim programina göre değerlendirilmesi. Yayımlanmamış Yüksek Lisans Tezi. İstanbul Aydın Üniversitesi Sosyal Bilimler Enstitüsü, İstanbul.

Dursun, A., \& Parim-Aydın, G. (2014). YGS 2013 matematik soruları ile ortaöğretim 9. sınıf matematik sınav sorularının Bloom taksonomisine ve öğretim programına göre karşılaştırılması. Eğitim Bilimleri Araştırmaları Dergisi, 4, (1), 16-37.

Eroğlu, D., \& Sarar-Kuzu, T. (2014). Türkçe ders kitaplarındaki dil bilgisi kazanımlarının ve sorularının yenilenmiş Bloom taksonomisine göre değerlendirilmesi. Başkent Üniversitesi Eğitim Dergisi, 1 (1), 72-80.

Ertürk, S. (1994). Eğitimde program geliştirme. Ankara: Meteksan.

Eyüp, B. (2012). Türkçe öğretmeni adaylarının hazırladığı soruların yeniden yapılandırılan Bloom taksonomisine göre değerlendirilmesi. Kastamonu Eğitim Dergisi, 20 (3), 965-982.

Gazel, A. A., \& Erol, H. (2011). İlköğretim 7. sınıf sosyal bilgiler ders programındaki kazanımların taksonomik açıdan değerlendirilmesi. Kuramsal Eğitimbilim Dergisi, 5 (2), 202-222.

Geçit, Y. ve Yarar, S. (2010). Coğrafya ders kitaplarındaki sorular ile çeşitli coğrafya sınav sorularının Bloom taksonomisine göre analizi. Marmara Coğrafya Dergisi, 22, 154-167.

Gezer, M., Şahin, İ. F., Sünkür, M. Ö. ve Meral, E. (2014). 8. Sınıf Türkiye Cumhuriyeti İnkılâp Tarihi ve Atatürkçülük dersi öğretim programı kazanımlarının revize edilmiş Bloom taksonomisine göre değerlendirilmesi. Bartın Üniversitesi Eğitim Fakültesi Dergisi, 3 (1), 433-455.

Girgin, E. (2012). İlköğretim 2. Kademe fen ve teknoloji ters kitaplarındaki ünite sonu değerlendirme sorularının incelenmesi. Yayınlanmış Yüksek Lisans Tezi. Trakya Üniversitesi Fen Bilimleri Enstitüsü, Edirne.

Gökler, Z. S., Aypay, A. ve Arı, A. (2012). İlköğretim ingilizce dersi hedefleri kazanımları sbs soruları ve yazılı sınav sorularının yeni Bloom taksonomisine göre değerlendirilmesi. Eğitimde Politika Analizi Dergisi, 1 (2), 115-133.

Gökulu, A. (2015). Fen ve teknoloji öğretmenlerinin yazılı sınav soruları ile TEOG sınavlarında sorulan fen ve teknoloji sorularının yenilenmiş Bloom taksonomisine göre incelenmesi. Route Educational and Social Science Journal, 2 (2), 434-446.

Güleryüz, H., \& Erdoğan, İ. (2018). Ortaokul Fen bilimleri dersi sınav sorularının Bloom’un bilişsel alan taksonomisine göre değerlendirilmesi: Muş ili örneği. Anemon Muş Alparslan Üniversitesi Sosyal Bilimler Dergisi, 6 (1) 43-49 
Güven, Ç. ve Aydın, A. (2017). Yedinci sınıf fen ve teknoloji dersi öğretim programı sorularının yenilenmiş Bloom taksonomisi bakımından analizi ve değerlendirilmesi. Atatürk Üniversitesi Kazım Karabekir Eğitim Fakültesi Dergisi, (35), 223-233.

Kablan, Z., Baran, T. ve Hazer, Ö. (2013). İlköğretim matematik 6-8 öğretim programında hedeflenen davranışların bilişsel süreçler açısından incelenmesi. Ahi Evran Üniversitesi Kırşehir Eğitim Fakültesi Dergisi (KEFA), 14 (1), 347-366.

Kahramanoğlu, E. (2013). İlköğretim fen ve teknoloji ders kitaplarının Bloom Taksonomisi açısından değerlendirilmesi. Yayınlanmış Yüksek Lisans Tezi. İstanbul Üniversitesi Eğitim Bilimleri Enstitüsü, İstanbul.

Kahramanoğlu, R. ve Deniz, T. (2017). An investigation of the relationship between middle school students' metacognitive skills, mathematics self-efficacy and mathematics achievement, Inonu University Journal of the Faculty of Education, 18 (3), 189-200. DOI: 10.17679/inuefd.334285.

Kaplan, A., Duran, M. ve Baş, G. (2016). Ortaokul öğrencilerinin matematiksel üstbiliş farkındalıkları ile problem çözme beceri algıları arasındaki ilişkinin yapısal eşitlik modeliyle incelenmesi. Inönü Üniversitesi Eğitim Fakültesi Dergisi, 17 (1), 1-16. DOI: 10.17679/iuefd.17119785

Karakelle, S. (2012). Üst bilişsel farkındalık, zekâ, problem çözme algısı ve düşünme ihtiyacı arasındaki bağlantılar. Eğitim ve Bilim, 37 (164), 237-250.

Karaman, M. ve Bindak, R. (2017). İlköğretim matematik öğretmenlerinin sınav soruları ile TEOG matematik sorularının yenilenmiş Bloom taksonomisine göre analizi. Current Research in Education, 3 (2), 51-65.

Kramarski B., Mevarech, Z. R. \& Arami, M. (2002) The effects of metacognitive training on solving mathematical authentic tasks. Educational Studies in Mathematics, 49 (2), 225-250.

Krathwohl, D. R. (2002). A Revision of Bloom's Taxonomy: An Overview. Theory into Practice, 41, 4, 212-264.

Krathwohl, D. R. (2009). Bloom taksonomisinin revizyonu: Genel bir bakış (çev. D. Köğce, M. Aydın ve C. Yıldız). Illkögretim Online, 8 (3), 1-7.

Köğce, D., \& Baki, A. (2009). Farklı türdeki liselerin matematik sınavlarında sorulan soruların Bloom taksonomisine göre karşılaştırılması. Kastamonu Eğitim Dergisi, 17 (2), 557-574.

Kuzu, T. S. (2013). Türkçe ders kitaplarındaki metin altı sorularının yenilenmiş Bloom taksonomisindeki hatırlama ve anlama bilişsel düzeyleri açısından incelenmesi. Cumhuriyet Üniversitesi Sosyal Bilimler Dergisi, 37 (1), 58-76.

Minisker, M. (2006). Matematiğin doğası, yapısı ve işlevi. H.Gür (Ed.), Matematik öğretimi içinde (s.1117). İstanbul: Lisans.

MEB. (2015). Temel eğitimden ortaögretime geçiş ortak sinav başarısının çeşitli değişkenler açısından incelenmesi. Ankara: MEB Yayınları. http://odsgm.meb.gov.tr/test/analizler/docs/OrtakSinavlar-Arastirma-Raporu.pdf sayfasından erişilmiş̧ir.

MEB.(2016). PISA 2015 ulusal rapor. Ankara: MEB Yayınları. http://odsgm.meb.gov.tr/test/analizler/docs/PISA/PISA2015_Ulusal_Rapor.pdf sayfasindan erişilmiştir.

MEB.(2018). Matematik dersi öğretim programi. http://mufredat.meb.gov.tr/ProgramDetay.aspx?PID=329 $\quad$ (Erişim tarihi: 08 Temmuz 2018) adresinden elde edilmiştir.

Miles, M. B. \& Huberman, A. M. (1994). Qualitative data analysis: an expanded sourcebook. (2nd Edition). Calif. : SAGE Publications.

Mullis, I. V. S., Martin, M. O., Fierros, E. G., Goldberg, A. L., \& Stemler, S. E. (2000). Gender differences in achievement: lEA's third international mathematics and science study (TIMSS). Chestnut Hill, MA: Boston College. https://timssandpirls.bc.edu/timss sayfasından erişilmiştir.

Mullis, I. V. S., Martin, M. O., \& Foy, P. (2008). TIMSS 2007 International Mathematics report: findings from IEA's trends in international mathematics and science study at the fourth and eighth 
grades. Chestnut Hill, MA: TIMSS \& PIRLS International Study Center, Boston College. https://timss.bc.edu/TIMSS2007/intl_reports.html sayfasından erişilmiştir.

Mullis, I. V. S., Martin, M. O., Foy, P. \& Hooper, M. (2016). TIMSS 2015 international results in mathematics. Chestnut Hill, MA: TIMSS \& PIRLS International Study Center, Boston College. http://timssandpirls.bc.edu/timss2015 sayfasından erişilmiştir.

Olkun, S., \& Toluk Uçar, Z. (2014). Illköğretimde etkinlik temelli matematik öğretimi (6.baskı). Ankara: Eğiten Kitap.

Omar, N., Haris, S. S., Hassan, R., Arshad, H. Rahmat, M., Ainun-Zainal, N. F. \& Zulkifli, R. (2012). Automated analysis of exam questions according to Bloom's taxonomy. UKM teaching and learning Congress 2011. Procedia - Social and Behavioral Sciences, (59), 297-303.

Ornstein, A. C., \& Hunkins, F. P. (2004). Curriculum foundations: Principles and theory. Boston: Allyn and Bacon.

Özçelik, D. A. (2013). Test hazırlama klavuzu. Ankara: Pegem.

Özdemir, S. M., Altık, S. ve Baki, N. (2015). Bloom'un yenilenmiş taksonomisine göre sosyal bilgiler öğretim programı kazanımlarının incelenmesi. Ĕ̆itim ve Öğretim Araştırmaları Dergisi, 4 (3) 363-375.

Schlesinger, J., \& Persky, A. (2015). Faculty learning community. Bloom's taxonomy in action (Erişim tarihi: 07 Temmuz 2018). https://www.mededportal.org/publication/10031.

Schoenfeld, A. H. (1985). Mathematical problem solving. Orlando, FL: Academic Press.

Sönmez, Ö. F., Koç, H. ve Çifçi, T. (2013). ÖSS, YGS ve LYS sınavlarındaki coğrafya sorularının Bloom taksonomisi bilişsel alan düzeyi açısından analizi. Karadeniz Araştırmaları, 36 (2013 Kış), 257275.

Şanlı, C. ve Pınar, A. (2017). Sosyal bilgiler dersi sınav sorularının yenilenen Bloom taksonomisine göre incelenmesi. Ilkögretim Online, 16 (3), 949-959.

Şenses, A. (2008). İlköğretim 6. sınıf sosyal bilgiler ders kitaplarındaki soruların kapsam-geçerlilik ve Bloom Taksonomisi’ne göre analizi. Yüksek lisans Tezi. Gaziosmanpaşa Üniversitesi Sosyal Bilimler Enstitüsü, Tokat.

Tahaoğlu, A. (2014). Ortaöğretim Türk edebiyatı dersi öğretim programı kazanımlarının bilişsel açıdan incelenmesi. Yüksek lisans Tezi. Bilkent Üniversitesi Eğitim Bilimleri Enstitüsü, Ankara.

Tanık, N. ve Saraçoğlu, S. (2011). Fen ve teknoloji dersi yazılı sorularının yenilenmiş Bloom taksonomisine göre incelenmesi. TÜBAV Bilim Dergisi, 4 (4), 235-246.

Tekin, H. (2009). Ĕ̈itimde ölçme ve değerlendirme. Ankara: Yargı Yayınevi.

Tolan, Y. (2011). Seviye belirleme sınavı (SBS) Sorularının fen ve teknoloji dersi ögretim programına uygunluğu ve Bloom Taksonomisine göre incelenmesi. Yayınlanmış Yüksek Lisans Tezi. Atatürk Üniversitesi Eğitim Bilimleri Enstitüsü, Erzurum.

Topçu, E. (2017). TEOG Tarih sorularının yenilenmiş Bloom Taksonomisine göre analizi. Uluslararası Türk Eğitim Bilimleri Dergisi, 2017 (9), 321-335. Retrieved from http://dergipark.gov.tr/goputeb/issue/34356/381023.

Tutkun, Ö. F. (2012). An overview on Bloom's revised taxonomy. Sakarya University Journal of Education, 2 (1), 14-22.

Tutkun, Ö. F., Demirtaş, Z., Erdoğan, D. G. ve Arslan, S. (2010). Bloom orijinal bilişsel alan sınıflaması ile yenilenmiş sınıflamanın karşılaştırılması. Akademik Sosyal Araştırmalar Dergisi, 3 (10), 350 359.

Üner, S. (2010). IX. ve X.sınıf kimya ders kitaplarındaki ve kimya sınavlarındaki soruların Bloom taksonomisine göre analizi ve ögrencilerin bilişsel düzeyleriyle ilişkinin tespit edilmesi. Yüksek lisans Tezi. Gazi Üniversitesi Eğitim Bilimleri Enstitüsü, Ankara.

Üner, S., Akkuş, H. ve Kormalı, F. (2014). Ortaöğretim kimya ders kitaplarındaki ve sınavlarındaki soruların bilişsel düzeyi ve öğrencilerin bilişsel düzeyiyle ilişkisi. Ahi Evran Üniversitesi Kırşehir Eğitim Fakültesi Dergisi, 15 (1), 137-154. 
Varış, F. (1998) . Eğitimde program geliştirme. Ankara: Alkım Yayınevi.

Yaz, Ö. V. ve Kurnaz, M. A. (2017). 2013 Fen Bilimleri öğretim programının incelenmesi. Uluslararası Türk Eğitim Bilimleri Dergisi, 5 (8), 173-184.

Yıldırım, A. ve Şimşek, H. (2013). Sosyal bilimlerde nitel araştırma yöntemleri (9. Baskı). Ankara: Seçkin Yayınevi.

Zorluoğlu, S. L., Kızılaslan, A. ve Sözbilir, M. (2016). Ortaöğretim kimya dersi öğretim programı kazanımlarının yapılandırılmış Bloom taksonomisine göre analizi ve değerlendirilmesi. Necatibey Eğitim Fakültesi Elektronik Fen ve Matematik Ĕgitimi Dergisi, 10 (1), 261-279.

Zorluoğlu, S., Şahintürk, A. ve Bağrıyanık, K. (2017). Analysis and evaluation of science course curriculum learning outcomes of the Year 2013 according to the Revised Bloom Taxonomy. Bartın Üniversitesi Eğitim Fakültesi Dergisi, 6 (1), 1-15. DOI: 10.14686/buefad.267190. 


\section{Extended Abstract}

\section{Introduction}

The changes and developments in the field of science and technology are reflected in the field of education as well as being individual and collective reflections, and in parallel with these changes in the field of education are also being discussed. Information, attitudes, skills, values and learning products desired to be provided to the students at every stage of education are transferred to the individuals in a planned and systematic way through the education programs.

An educational program has four main elements. These items are goal, content, learning-teaching process and assessment. The concept of goal includes the behaviours to be learned by the students (Ertürk, 1994, p. 26). Goals have a more critical importance than other teaching curricula since they constitute the initial phase of teaching. It is necessary to determine the goals correctly, to prepare appropriate content to be gained to the students, to measure whether the content prepared is successful or not and to evaluate the results (Bümen, 2006). The gradual classification of acquisitions in curricula according to their level of knowledge, attitudes and skills (Tutkun, 2012) is aimed at facilitating mental restructuring of learners and active learning (Anderson and Krathwohl, 2001, Bloom, 1956).

In the renewed taxonomy, names and verb states are separated into two dimensions: Information and Cognitive Process. In the information dimension; there are information based on phenomena, conceptual knowledge, operational knowledge, and cognitive knowledge. The renewed taxonomy, like the old version, consists of six steps. (Anderson, 2005; Krathwohl, 2009). In general, the renewed Bloom Taxonomy; it can be said that the development of program development goals, learning-teaching processes, measurement and evaluation practices and current trends towards teacher training fields are an innovation (Tutkun, Demirtaş, Erdoğan and Arslan, 2010).

Rapid change in science and technology in our country, changing needs of individual and society, innovation and developments in teaching and learning theories and approaches, taking into account the role expected from the individual, is aimed at the primary school mathematics teaching program prepared in for 2015 and lastly in 2018 program updates and changes were made (MEB, 2018). When the relevant literature was examined, no research was conducted to examine the acquisitions of the Primary School Mathematics Teaching Program. In this research, it was aimed to determine the taxonomic levels of the acquisitions by examining the acquisitions at the class level in the Primary School Mathematics Teaching Program according to the Renewed Bloom Taxonomy.

\section{Method}

Qualitative research methods used in the research were document review. The taxonomic levels of the 229 acquisitions in the study, which were published in the Primary School Mathematics Teaching Program (1st - 4th grades) published in 2018, were determined according to the Revised Bloom Taxonomy. The data source of the research is the course acquisitions in Primary School Mathematics Teaching Program (1st - 4th grade) which the Ministry of National Education published in 2018. The researches in the field were examined and a coding key for the cognitive domain steps and sub-steps of the Renewed Bloom Taxonomy was established. In 
order to determine the location of the 229 acquisitions in the primary school mathematics curriculum (1st - 4th grade) in the taxonomic table, the investigator determined the verbal expressions of each acquisition.

In order to ensure the validity and reliability of the obtained data; as to the order in which the verb expressions contain; In addition to the researchers who carried out the study, the coding made by taking the opinions of four field experts, two in the qualitative research field and two experts in the field of mathematics education, were compared and the final table was given. In order to ensure the reliability of the data obtained by document analysis, Miles and Huberman's (1994) "Opinion Alliance / (Opinion Alliance + Opinion Separation) x 100" formula was used. The reliability ratio between the experts was determined as $88 \%$.

\section{Results}

According to research findings, it was determined that the evaluation and creation stages, which are included in the recall, application and analysis sub-stages of approximately one-fourth of the first grade course acquisitions in the Primary School Mathematics Curriculum, are the least cognitive process steps represented. It has been determined that the evaluation and creation stages in which more than half of the $2^{\text {nd }}$ grade course acquisitions in the primary school Mathematics Teaching Program are included in the application and understanding sub-stages are the least cognitive process steps represented. It has been determined that the evaluation and creation stages in which the approximately half of the 3rd grade course acquisitions in the elementary school mathematics curriculum are included in the application sub clause are the least represented cognitive process steps. It has been determined that the evaluation, creation and analysis steps of the cognitive process steps that are included in the remembrance, understanding and application sub-stages of the 4th grade course acquisitions in the primary school mathematics curriculum are the least represented cognitive process steps. Based on the research findings, the steps with the most acquisitions after the application step, where the acquisitions are highest at the application level at all class levels; remembering, understanding and analysis step. Evaluation and creation were determined to be the least cognitive process steps.

\section{Discussion and Conclusion}

When the results of the research are examined, it is determined that the acquisitions of the 1-4th grade courses in Primary School Mathematics Teaching Program are concentrated in lower level steps such as application, understanding and remembering, which includes lower level cognitive steps, and less acquisitions including higher level cognitive steps such as analysis, creation and evaluation. When examining the related literature, it is seen that the primary school mathematics curriculum is not based on the cognitive process dimension of the Bloom Taxonomy of the Renewed. In the secondary school mathematics curriculum (grades 6-8), exam questions prepared for mathematics course, there are high level cognitive steps such as analysis, creation and evaluation which concentrate on lower level steps such as application, understanding and recall, which include lower level cognitive steps in the questions that are prepared for the exam questions prepared in the textbooks. In the direction of the research results, it can be said that in the mathematics education, both the examination questions prepared for the mathematics course in the curriculum and the questions in the national level are not enough to give the students high level cognitive skills. As a reflection of this situation, today's important skills such as problem 
solving, reasoning, estimation, pattern searching which are necessary for our students are not gained enough (Olkun and Toluk Uçar, 2014). The importance of lower level cognitive skills in teaching programs and in other educational activities related to curriculum is due to the fact that in the recent years the students have got low scores in mathematics courses (MEB, 2015) in central joint exams made at the national level and in the international assessments where high level cognitive skills are measured, Mullis, Martin, Foy, and Hooper, 2016), although the mathematical averages are well below the average of other countries (MEB, 2016, Mullis, Martin, Fierros, Goldberg and Stemler, 2000).

In the direction of the research findings it is suggested that in the acquisitions prepared for the students at the grade level in the primary school in accordance with the teaching perspective of the Primary School Mathematics Curriculum, the acquisitions (analysis, evaluation, creation) including the higher level cognitive steps should be given more importance. 